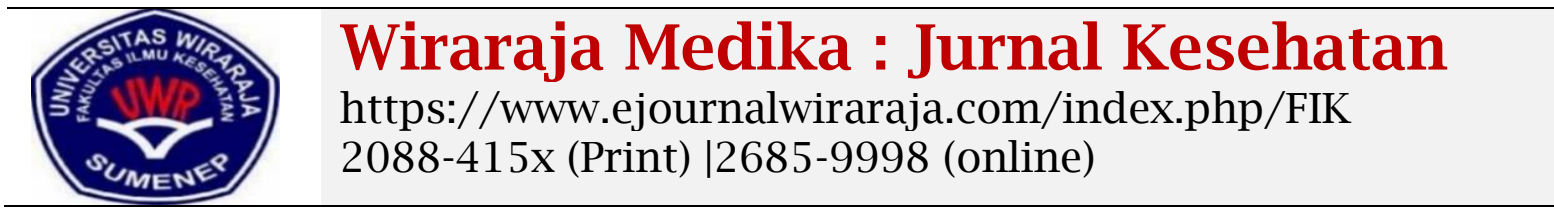

\title{
Relationship Between Knowledge And Behavior Of Vulva Hygiene When Menstruate With The Event Of Pruritus Vulvae In Adolescents
}

\author{
Annah Hubaedah \\ Universitas PGRI Adi Buana Surabaya \\ Email: annah@unipasby.ac.id* \\ *Corresponding author
}

\begin{tabular}{|c|c|}
\hline $\begin{array}{l}\text { INFORMASI } \\
\text { ARTIKEL }\end{array}$ & ABSTRACT \\
\hline $\begin{array}{l}\text { Sejarah artikel: } \\
\text { Received: } 10-04-2020 \\
\text { Revised: } 06-05-2020 \\
\text { Accepted: } 23-05-2020\end{array}$ & $\begin{array}{l}\text { Pruritus vulvae is a disorder characterized by itching in the external genitals } \\
\text { of women. Pruritus vulvae can be caused by bacteria, fungi, and viruses. The } \\
\text { purpose of this study is to determine the relationship between knowledge } \\
\text { and behavior about hygiene vulva during menstruation with the incidence of }\end{array}$ \\
\hline $\begin{array}{l}\text { Keywords: } \\
\text { knowledge, behavior, } \\
\text { hygiene vulva, } \\
\text { menstruation, } \\
\text { pruritus vulvae }\end{array}$ & $\begin{array}{l}\text { pruritus vulvae in adolescent girls because according to preliminary data } \\
\text { students do not know what vulva pruritus is. This study used an } \\
\text { observational research method with a cross-sectional approach. The } \\
\text { population is all seventh-grade female teenagers at SMP Negeri } 1 \text { Sepulu } \\
\text { Bangkalan with } 98 \text { people. Samples were obtained by } 79 \text { people who were } \\
\text { determined by a simple random sampling technique. The measuring } \\
\text { instrument used was a knowledge level questionnaire about pruritus vulvae, } \\
\text { in female students of class VII SMP Negeri } 1 \text { Sepulu Bangkalan. Statistical } \\
\text { tests using Lambda } \rho \leq 0.05 \text {. The results showed that there was a relationship } \\
\text { between knowledge about vulva hygiene }(\mathrm{p}=0.028<\alpha=0.05 \text { ) and behavior } \\
\text { about vulva hygiene }(\mathrm{p}=0.006<\alpha=0.05) \text { when menstruating with the } \\
\text { occurrence of vulvae pruritus in adolescent girls in class VII at Sepulu } \\
\text { Bangkalan Middle School. For this reason, vulva hygiene behavior in young } \\
\text { women must be improved because good vulva hygiene behavior will reduce } \\
\text { the incidence of pruritus vulvae. }\end{array}$ \\
\hline
\end{tabular}

\section{INTRODUCTION}

Adolescence is a period where adolescents experience the development and maturation of reproductive organs. Changes in maturity of the reproductive organs in women is menstruation. When they are teenagers, students are not fully informed about menstruation. Knowledge about Menstruation is still considered taboo because access to information is still lacking from both the family and school environment. thus it limits adolescent knowledge about menstruation especially vulva hygiene (Anggraeni \& Sari, 2019; Ety et al., 2019)

The behavior of vulva hygiene during menstruation is not right, such as dressing pads every 4 hours, after urinating and then dried using a tissue or dry towel (Fatkhuli Janah et al., 2016). This behavior will continue to be adhered to by young women from day today. Teenagers will often ignore the cleanliness of genitalia because of the lack of understanding of menstrual hygiene (Astuti, 2017).

As a result of inappropriate hygiene behavior results in adverse effects on reproductive health. One problem that is often experienced by adolescents during menstruation is pruritus vulvae (Muthoharoh \& Widiyawati, 2019). pruritus vulvae is a symptom of severe itching and irritation around the vulva. Poor hygiene behavior causes fungi and bacteria to flourish, and causes itching and irritation in the area around the vulva (Rohmawati, 2018). If the infection is left and not treated properly, it will cause infections such as acute candida infection, bacterial vaginosis and trichomoniasis (Tri \& Indah, 2018)

Research conducted by (Rohmawati, 2018) at SMA Negeri 1 Ngimbang Lamongan in young women shows that 79 people (100\%) have experienced pruritus 
vulvae during menstruation. Whereas many as $15.2 \%$ always feel pruritus vulvae during menstruation and $84.8 \%$ experience pruritus vulvae not every day during menstruation. Winerungan et al.,(2013) showed that of 167 young women in SMP Negeri 8 Manado. 107 people (64.1\%) experienced itching. And a study conducted by Wardani \& Anggraini, (2015) showed that of 59 teenage girls in the Pisangan Community Health Center area, 36 people (61\%) experienced itching in the pubic area. Based on the results of interviews with 10 class VII students at SMP Negeri 1 Sepulu on February 4, 2017, data obtained showed that 7 students (70\%) felt itching on their genitals during menstruation, and 3 students (30\%) did not feel itching at genitals during menstruation.

Pruritus vulvae is a disorder characterized by a sensation of severe itching from the female external genitalia (Hudson, 1971; Ríos Yuil et al., 2014). The causes of pruritus vulvae are infections, infections (scabies, pediculosis pubis, Enterobius vermicularis), box dermatitis (irritant and allergic) (Kandanearachchi et al., 2018; Kaur \& Kalsy, 2017). To alleviate the annoying itching it is necessary to know the cause first, namely (a) By eliminating the cause of itching, the complaints will also disappear, (b) Always maintain cleanliness in the pubic area, (c) use clean water when a splash or use sterile tissue, (d) use underwear that is not tight and made of cotton, Avoid the use of soap, spray and vaginal fragrances as well as types of drugs that can irritate the surface of the genitals, (e) It is better to use soft baby soap instead fragrant soap or detergent, and (f) traditional recipes can also be used to treat vaginal itching.

Pruritus vulvae often occurs in adolescents during menstruation. This is because during menstruation the genital area becomes moister. When menstruation blood and sweat come out and stick to the vulva, if at that time the teenager does not maintain the cleanliness of genitalia properly, fungi and bacteria that will flourish, causing itching. Excessive itching makes teenagers can not stand wanting to scratch it. Meanwhile, when scratched, the surface of the skin will be chafed, exposed and inflamed (Randolph \& Hopkins, 2015).

Vulva hygiene during menstruation is most likely influenced by the level of knowledge about reproductive health. Low knowledge about reproductive health will allow women not to behave hygiene during menstruation and can endanger their own reproductive health (Gupte et al., 2009; Rahman et al., 2014).

One of the behaviors that is highly emphasized for adolescents who are menstruating is maintaining the cleanliness of the genetal area. Hygiene during menstruation can be done by changing pads every 4 hours or 3 to 4 times a day. After bathing or defecating, washing the vagina from the front to the back of the anus, the vagina is dried with a tissue or towel so that it is not moist, the use of good underwear made from materials that easily absorb sweat (Izzati \& Agustiani, 2014; Setianingsih \& Putri, 2017; Suryati, 2012).

Knowledge and behavior regarding reproductive health, especially about vulva hygiene during menstruation should be given at school. This is done to prevent knowledge bias about reproductive health among adolescents. Schools must collaborate with cross-sectors such as the health department and puskesmas to provide information on reproductive health to improve understanding, attitudes and positive behavior of young women about reproductive health, especially about vulva hygiene, in order to improve their reproductive health.

\section{RESEARCH METHODS}

This research was an observational study, with a Lambda test with $\rho \leq 0.05$. data collection is done by primary means. The population in this study were all students of class VII in SMP Negeri 1 Sepulu as many as 98 people who had menstruated. Sampling technique using Simple Random Sampling,

Sugiyono, (2012) The sample in this study used the Solvin formula with a total sample of 79 and met the inclusion criteria (a) healthy students, (b) students who had menstruated (c) were willing to do the research. And meet the exclusion criteria

\section{2 | Wiraraja Medika}


(a) students who are not in place (b) refuse to participate

This research was conducted at SMP Negeri 1 Sepulu District Bangkalan District, in March-June 2017. The research instrument was a questionnaire to assess the knowledge and behavior of vulva hygiene during menstruation and the incidence of vulvar pruritus. The data that has been collected will be tabulated data, and data analysis using the log-linear model test with $\rho \leq 0.05$. Lambda statistical tests are used for data that has 2 independent variables with ordinal scale.

\section{RESEARCH RESULT}

The results were obtained from a population of 98 female teenage girls at SMPN 1 Sepulu Bangkalan, after sampling with a simple random sampling technique, the respondents obtained were 79 people.

\section{A. General Data}

Table 1. Distribution of respondent's age frequency

\begin{tabular}{cccc}
\hline No & $\begin{array}{c}\text { Age } \\
\text { (years) }\end{array}$ & $\begin{array}{c}\text { Amount } \\
\text { (female) }\end{array}$ & Percentage \\
\hline $\mathbf{1}$ & $12-13$ & 45 & 57 \\
\hline $\mathbf{2}$ & $14-15$ & 33 & 41,8 \\
\hline $\mathbf{3}$ & $16-17$ & 1 & 1,3 \\
\hline \multicolumn{2}{c}{ Total } & 79 & 100 \\
\hline \multicolumn{2}{c}{ Based on the table above it is }
\end{tabular}

known that the majority of young women aged 12-13 years were 45 (57\%).

\section{B. Special Data}

1. Knowledge.

Table 2. Frequency distribution of the level of knowledge about vulva hygiene during menstruation in young women.

\begin{tabular}{cccc}
\hline No & Knowledge & Frequency & Percentage \\
\hline $\mathbf{1}$ & Less & 41 & 51,9 \\
\hline $\mathbf{2}$ & Sufficient & 24 & 30,4 \\
\hline $\mathbf{3}$ & Good & 14 & 17,7 \\
\hline & Total & 79 & 100 \\
\hline & Based on the table above shows that
\end{tabular}
most of the knowledge of young women about vulva hygiene during menstruation is classified in the category of less than 41 people (51.9\%).

\section{Behavior.}

Table 3. Frequency distribution of vulva hygiene behavior during menstruation in young women

\begin{tabular}{cccc}
\hline No & Behavior & $\begin{array}{c}\text { Amount } \\
\text { (female) }\end{array}$ & Percentage \\
\hline $\mathbf{1}$ & Less & 50 & 63,3 \\
\hline $\mathbf{2}$ & Sufficient & 22 & 27,8 \\
\hline $\mathbf{3}$ & Good & 7 & 8,9 \\
\hline & Total & 79 & 100
\end{tabular}

Based on table 3 shows that most of the behavior of young women about vulva hygiene during menstruation is classified in the category of less that is equal to 50 people (63.3\%).

3.The incidence of pruritus vulvae Table 4 Distribution of frequency of occurrence of pruritus vulvae in young women.

\begin{tabular}{cccc}
\hline $\begin{array}{c}\text { N } \\
\text { o }\end{array}$ & $\begin{array}{c}\text { pruritus } \\
\text { vulvae }\end{array}$ & frequency & Percentage \\
\hline $\mathbf{1}$ & Yes & 59 & 74,7 \\
\hline $\mathbf{2}$ & No & 22 & 25,3 \\
\hline & Total & 79 & 100 \\
\hline
\end{tabular}

Based on Table .4 it is known that the majority of girls who experience pruritus vulvae during menstruation are 59 people (74.7\%).

\section{Cross Tabulation Results}

Table 5 Cross-tabulation of knowledge of menstrual vulva hygiene with the incidence of pruritus vulvae in young women

\begin{tabular}{lcccc}
\hline \multirow{2}{*}{ No } & Knowledge of & \multicolumn{2}{c}{ PV incident } & Total \\
\cline { 3 - 4 } & vulva hygiene & No & Yes & \\
\cline { 3 - 4 } & $\boldsymbol{\Sigma}$ & $\boldsymbol{\Sigma}$ & $\boldsymbol{\Sigma}$ \\
\hline $\mathbf{1}$ & Less & 0 & 41 & 41 \\
\hline $\mathbf{2}$ & Enough & 9 & 15 & 24 \\
\hline $\mathbf{3}$ & Good & 11 & 3 & 14 \\
\hline & Total & 20 & 59 & 79 \\
\hline
\end{tabular}

Based on table 5 shows that of 41 young women with less vulva hygiene knowledge, 41 people (100\%) have pruritus vulvae. 24 young women with sufficient knowledge found 15 people (62.5\%) experienced pruritus vulvae, 9 people (37.5\%) did not experience pruritus vulvae, and 14 young women with good knowledge found 3 people experienced pruritus vulvae and 11 people $(78,6 \%)$ did not experience pruritus vulvae. From the Lambda Test statistics results obtained a p-value of 0.028 ( $\mathrm{p}<\mathrm{a} 0.05$ ), which means that Ho is rejected and H1 is accepted. 
Table 6 Cross-tabulation of vulva hygiene behavior during menstruation with the incidence of pruritus vulvae in young women.

\begin{tabular}{ccccc}
\hline \multirow{2}{*}{ No } & PV incident & \multicolumn{2}{c}{ PV incident } & \multirow{2}{*}{ Total } \\
\cline { 3 - 4 } & & No & Yes & \\
\cline { 3 - 4 } & $\boldsymbol{\Sigma}$ & $\boldsymbol{\Sigma}$ & $\boldsymbol{\Sigma}$ \\
\hline $\mathbf{1}$ & Less & 3 & 47 & 50 \\
\hline $\mathbf{2}$ & Sufficient & 10 & 12 & 22 \\
\hline $\mathbf{3}$ & Good & 7 & 0 & 7 \\
\hline & Total & 20 & 59 & 79 \\
\hline
\end{tabular}

Based on table 6 shows that as many as 50 young girls with less vulva hygiene behavior found 47 people $(94 \%)$ had pruritus vulvae, 3 people (6.0\%) did not. pruritus vulvae. 22 young women with vulva hygiene behavior were enough to get 12 people (54.5\%) experiencing pruritus vulvae, 10 people $(45.5 \%)$ did not experience pruritus vulvae. And 7 people with good vulva hygiene behavior found that 7 people $(100 \%)$ did not experience pruritus vulvae. From the results of the Lambda Test statistics obtained p-value 0.006 ( $\mathrm{p}<\mathrm{a} 0.05)$.

\section{DISCUSSION}

Knowledge of vulva hygiene during menstruation in seventh grade teenage girls at SMPN 1 Sepulu Bangkalan

Half of young women respondents lack knowledge about vulva hygiene during menstruation Notoadmojo,

Knowledge is the result of human sensing, or the result of someone's knowledge of objects through their senses. The truth of knowledge is obtained by solving problems faced in the past. The higher level of knowledge will be reflected in daily behavior. Some factors that cause lack of knowledge are age and education. Age can also affect one's knowledge, age is closely related to the level of technical or psychological maturity. Increasing age is directly proportional to the knowledge a person has.

Education is a process of shaping one's speed intellectually and emotionally towards nature and fellow human beings (Notoadmodjo, 2012) The higher one's education, it is expected that knowledge and skills will increase.

The learning process is influenced by various factors from the inside, such as motivation and external factors in the form of available information facilities, as well as socio-cultural conditions. Someone who has more sources of information will have broader knowledge (Prawirohardjo, 2016).

Based on research conducted in the field, it was found that many young women who have lack of menstrual hygiene knowledge due to various factors, one of which is age. In this study the age of adolescent girls ranged from 12-13 years where the age is included in the category of early adolescence.

Early adolescents experience psychological development starting from the attitude of acceptance of changes in physical conditions, the development of ways of thinking but being over-estimated. At this stage teenagers consider menstrual hygiene is not so important, so they do not find out about things related to their reproductive health (Fleeson et al., 2017; Supatmi \& Adyani, 2009).

Another factor affecting the lack of knowledge of seventh grade girls at SMPN 1 Sepulu Bangkalan is the lack of information about menstrual hygiene. Society considers reproductive health is still taboo discussed by adolescents. This limits communication between parents and teens about menstrual hygiene. As a result, adolescents lack understanding, lack understanding and sometimes make wrong decisions regarding reproductive health. In addition, seventh grade teenagers did not get information about menstrual hygiene at school. Lessons about the new reproductive system will be given when teenagers enter class VIII (Supatmi \& Adyani, 2009; Timbawa et al., 2015).

The mass media also has an important role in conveying information about menstrual hygiene. One of the very important mass media is the internet. Many teenagers have used the internet to access various information (Ade $S$ et al., 2016; Fleeson et al., 2017; Nurchandra et al., 2020). But most teenagers do not optimize the function of these tools, young women prefer to access information outside of health. The more young women are open in accessing information about menstrual hygiene, the broader the insight and understanding of reproductive health will be. With good knowledge, young women will respond to menstruation with things or positive hygiene behaviors.

\section{4 | Wiraraja Medika}




\section{Behavior about vulva hygiene during menstruation in seventh grade girls at SMPN 1 Sepulu Bangkalan.}

Almost all respondents of young women behavior about vulva hygiene during menstruation behave less. According to Mamdy, (2001); Notoatmodjo, (2015); Notoatmojo, (2010). tried to analyze human behavior from the level of health. The health of a person or community is influenced by 2 main factors, namely behavioral factors and non-behavioral factors. Furthermore, the behavior itself is determined by 3 factors, namely predisposing factors, manifested in knowledge, attitudes, beliefs, values and so on, supporting factors, manifested in the physical environment, whether or not health facilities or facilities are available and whether pusher, which is manifested in the attitudes and behavior of health workers, or other officers who are a reference group of community behavior. The theory in this study will be used to predict that knowledge will influence attitudes which then determine the merits of one's behavior to improve their health.

Based on research conducted in the field, a factor that might cause menstrual hygiene behavior for seventh grade girls at SMPN 1 Sepulu is the lack of knowledge of young women about vulva hygiene. Adolescent knowledge about reproductive health tends to be inadequate, causing them to have inappropriate menstrual hygiene behaviors, because according to (Pratiwi \& Rodiani, 2015). positive and negative knowledge will influence one's behavior. With the correct knowledge of hygiene during menstruation, it will change the attitudes of young women and influence behavior when performing menstrual hygiene. Good knowledge encourages good and right behavior while less or wrong knowledge will lead to improper behavior too.

In addition, thinking patterns and beliefs about menstrual hygiene also affect the behavior of young women. Teenagers often underestimate the practice of menstrual hygiene, because they believe that the usual practice of hygiene will not have an impact on their reproductive health. They assume that their hygiene practices are appropriate and correct, so they maintain the behavior. The right thoughts and beliefs will have an impact on the right behavior as well, so it is necessary to provide health education to young women to increase knowledge, thoughts, and beliefs, so that changes in health behavior (vulva hygiene) are better (Herawati \& Khatimah, 2016; Astuti, 2017)

\section{The occurrence of pruritus vulvae in seventh-grade girls in SMPN 1 Sepulu Bangkalan}

Almost all young women experience pruritus vulvae during menstruation. Based on the results of answers to a questionnaire for young women about the incidence of pruritus vulvae, data obtained that more than half of young women experience pruritus vulvae at the beginning of menstruation, less than half of young women experience pruritus vulvae, not every menstruation, and some small teenage girls respond to pruritus vulvae by scratching

Sulaikha, (2018) said, Pruritus vulvae is a disorder characterized by an itchy sensation in a woman's external genitalia. Pruritus vulvae is influenced by menstrual hygiene practices and home hygiene facilities. Women who experience Pruritus vulvae often have poor vulva care.

During menstruation blood and sweat that comes out sticks to the vulva so that the genital area becomes moist. the fungus Candida Albicans, Trichomonas vaginalis, Gardnerella vaginalis which is in the blood of genitalia thrives and causes itching and infection in the area $(6,11)$.

Based on research conducted in the field, a factor that might cause pruritus vulvae during menstruation is hygiene behavior. Most respondents have poor hygiene practices such as cleaning the genitals from back to front, using betel leaf soap, using tight underwear during menstruation. Ignorance of young women in caring for and cleaning these female 
organs, can trigger the proliferation of fungus or bacteria, this causes young women to experience pruritus vulvae. Pruritus vulvae is one of the symptoms that can cause vaginal infections, such as acute candida infection, bacterial vaginosis, and trichomoniasis. If young women do not have good immunity, infection will occur soon. Therefore, in addition to increasing menstrual hygiene behavior, adolescents must also increase body immunity to prevent pruritus vulvae and infection.

\section{Relationship of knowledge about vulva hygiene during menstruation with the incidence of Pruritus vulvae}

Based on the results of the crosstabulation in table 6 knowledge and the incidence of pruritus vulvae showed that all 41 young women with vulva hygiene knowledge, all (100\%) experienced pruritus vulvae. Whereas 24 people with sufficient knowledge as many as 15 people (62.5\%) experienced pruritus vulvae and 9 people (37.5\%) did not experience pruritus vulvae. And as many as 14 people who have good knowledge as many as 3 people (21.4\%) experienced pruritus vulvae and 11 people (78.6\%) did not experience pruritus vulvae.

High knowledge about the health of female reproductive organs, does not guarantee to have good behavior to improve their health status.

Research conducted at SMAN 1 Ngimbang Lamongan on 79 class X and XI students showed that there was a significant relationship between the practice of menstrual hygiene and the incidence of pruritus vulvae during menstruation with $\mathrm{p}=0.001(\mathrm{p}<\alpha(0.05)$.

This is in accordance with field research, young women who have good knowledge and do not necessarily not experience pruritus vulvae during menstruation. This is because the incidence of pruritus vulvae during menstruation is not only influenced by knowledge factors, but is also influenced by hygiene practices. Young women who have good knowledge and do not necessarily practice or do vulva hygiene in their behavior. Because someone in determining attitudes and behaviors that are intact in addition to being determined by knowledge, is also influenced by thoughts, beliefs, and emotions that play an important role.

In addition, research conducted by Sari, (2016) on 62 respondents at YMS Bandung shelter shows that there is a significant relationship between knowledge and personal hygiene behavior.

Lack of knowledge will certainly cause bad behavior and will increase the risk of disturbing the moisture balance in the vaginal area especially during menstruation, if women do not pay attention to proper vaginal area hygiene, there will be a variety of complaints that can lead to pruritus vulvae. Giving good knowledge about reproductive health to adolescents will certainly have a good impact in preventing the occurrence of pruritus vulvae. Lots of knowledge about the cleanliness of the reproductive organs that can be done by teens in maintaining vaginal hygiene, especially during menstruation.

\section{Relationship behavior about vulva hygiene during menstruation with the incidence of Pruritus vulvae}

Based on the results of crosstabulation of behavior with the incidence of pruritus vulvae showed that 50 adolescent girls with less vulva hygiene behavior as many as 47 people (94\%) experienced pruritus vulvae and 3 people (6\%) did not experience pruritus vulvae. While 22 people who had sufficient behavior as many as 12 people (54.5\%) experienced pruritus vulvae and 10 people (45.5\%) did not experience pruritus vulvae. And 7 people who have good behavior as many as 7 people (100\%) did not experience pruritus vulvae.

Thus it can be concluded that the behavior of adolescent girls about vulva hygiene influences the incidence of pruritus vulvae during menstruation. This is consistent with the results of Rohmawati, (2018) conducted on class X and XI students at SMAN 1 Ngimbang Lamongan, showing that of 79 respondents, 33 respondents who had good menstrual hygiene practices, did not experience pruritus vulvae during menstruation. and it can be concluded that 
there is a relationship between the practice of menstrual hygiene and the incidence of pruritus vulvae during menstruation.

Behavior is something that can cause Pruritus vulvae. Women who experience Pruritus vulvae often have poor vulva care. It is important to know the personal habits of the respondent that can cause a person to experience pruritus vulvae, for example, the use of soap to clean genital organs, the use of women's health products such as cleaning the tight female area of the underwear, the condition of the genital area which is often moist and unclean.

Field research results indicate that changes in good menstrual hygiene behavior are urgently needed to improve reproductive health and prevent pruritus vulvae. Bad behavior or habits of young women in maintaining the cleanliness of external genitalia during menstruation such as cleaning the genitals from back to front, using betel leaf soap, using tight underwear during menstruation, can trigger the proliferation of fungus or bacteria, this will have an impact on the incidence of pruritus vulvae.

\section{CONCLUSIONS And RECOMMENDATION Conclusion}

From the results of the study concluded: (1) Most of the level of knowledge of seventh-grade girls in SMAN 1 Sepulu Bangkalan about vulva hygiene in the category of fewer than 41 respondents (51.9\%); (2) Most of the level of behavior of young women in SMPN 1 Sepulu Bangkalan about vulva hygiene in the category of fewer than 50 respondents (63.3\%); (3) The incidence of pruritus vulvae during menstruation in adolescent girls in grade VII of SMP 1 Sepulu was 59 respondents (74.7\%); (4) There is a significant relationship between knowledge ( $\mathrm{p}(0.028)$ $<\alpha(0.05))$ and behavior ( $\mathrm{p}(0.006)<\alpha(0.05))$ about menstrual vulva hygiene with the incidence of pruritus vulvae in class VII young women at SMP Negeri 1 Sepulu Bangkalan.
So it can be concluded that young women who are given knowledge about the Hygiene vulva will change their behavioral attitudes about the Hygiene vulva during menstruation.

\section{BIBLIOGRAPHY}

Ade S, E., Wahyuningsih, W., \& Haryani, K. (2016). Pendidikan Kesehatan dengan Media Slide Efektif dalam Meningkatkan Pengetahuan tentang Perawatan Vulva Hygiene pada Siswi Kelas VIII SMP 2 Sedayu Bantul. Jurnal Ners Dan Kebidanan Indonesia. https://doi.org/10.21927/jnki.2016.4( 1). $6-10$

Anggraeni, W., \& Sari, K. I. P. (2019). Hubungan Pengetahuan Remaja Tentang Menstruasi Dengan Tingkat Kecemasan Dalam Menghadapi Menarche Pada Siswi Kelas IV Dan V SDI Darul Hikmah Krian Sidoarjo. Nurse and Health: Jurnal Keperawatan.

https://doi.org/10.36720/nhjk.v7i1.36

Anita Herawati, D. M., \& Khatimah, H. (2016). Hubungan Pekerjaan dan Vulva Hygiene Dengan Kejadian Keputihan Pada Ibu Hamil di PUSKESMAS Sungai Bilu Banjarmasin. Dinamika Kesehatan.

Astuti, R. (2017). Hubungan Pengetahuan tentang Personal Hygiene dengan Perilaku Personal Hygiene Saat Menstruasi pada Remaja Putri Kelas XI di SMA Negeri 1 Pajangan Bantul. Universitas 'Aisyiyah.

Ety, D., Suriah, S., \& Fairus, F. (2019). Perilaku Personal Hygiene Remaja Putri Suku Nuaulu Dalam Tradisi Pinamu di Kabupaten Maluku Tengah. Jurnal Ilmiah Kesehatan Diagnosis. https://doi.org/10.35892/jikd.v14i1.9 1

Fatkhuli Janah, A., Sampurno Ridwan, E., \& Wahyuningsih, W. (2016). Perilaku Vulva Hygiene Berhubungan dengan Kejadian Keputihan pada Remaja Putri Kelas XII SMA GAMA 3 Maret Yogyakarta. Jurnal Ners Dan Kebidanan Indonesia. https://doi.org/10.21927/jnki.2013.1( 2).66-70

Fleeson, W., Jayawickreme, E., Jones, A. B. A. P., Brown, N. A., Serfass, D. G., 
Sherman, R. A., Mestdagh, M., Pe, M., Pestman, W., Verdonck, S., Kuppens, P., Tuerlinckx, F., O'Connor, M. C., Paunonen, S. V, Baumert, A., Schmitt, M., Perugini, M., Johnson, W., Blum, G. S., ... Matyjek-, M. (2017). pengaruh pendidikan kesehatan terhadap tingkat pengetahuan remaja putri tentang vulva hygine pada saat menstruasi di smp. Journal of Personality and Social Psychology. https://doi.org/10.1111/j.14697610.2010.02280.x

Gupte, P., Patil, S., \& Pawaskar, R. (2009). Vulvovaginal hygiene and care. In Indian Journal of Sexually Transmitted Diseases.

https://doi.org/10.4103/0253-

7184.62778

Hudson, C. N. (1971). Pruritus vulvae. British Medical Journal. https://doi.org/10.1136/bmj.1.5750.6 56

ismi sulaikha. (2018). hubungan personal hygiene saat menstruasi dengan kejadian pruritus vulvae pada remaja (Studi di SMP pondok Pesantren Darul Muttaqim Jombang). Personal Hygiene Saat Menstruasi Dengan Pruritus Vulvae.

https://doi.org/10.1093/imamci/dnt0 37

Izzati, W., \& Agustiani, R. (2014). Hubungan Pengetahuan Dengan Pelaksanaan Personal Hygiene Genitalia Saat Menstruasi Pada Remaja Putri Kelas Ix Smp Negeri. Jurnal Kesehatan.

Kandanearachchi, P., Sahu, B., Antonakou, A., \& Papoutsis, D. (2018). A Survey of Management of Vulvar Disorders In The Primary Health Care Setting In An Urban Area of England. Archives of Hellenic Medicine.

Kaur, J., \& Kalsy, J. (2017). Study of Pruritus Vulvae In Geriatric Age Group In Tertiary Hospital. Indian Journal of Sexually Transmitted Diseases.https://doi.org/10.4103/025 3-7184.192632

Mamdy. (2001). Pendidikan Kesehatan dan Ilmu Perilaku. Jurnal Ilmu Kesehatan UHAMKA.

Muthoharoh, S., \& Widiyawati, R. (2019). Pengaruh Health Education Terhadap Perilaku Vulva Hygiene Saat Menstruasi Anak SD Umur 11 - 13 Tahun di SDN Mojosari Kabupaten Mojokerto. Nurse and Health: Jurnal Keperawatan.

8 | Wiraraja Medika https://doi.org/10.36720/nhjk.v7i1.34 Notoadmodjo. (2012). Pendidikan dan Perilaku Kesehatan. In Metodologi Penelitian Kesehatan. Pt Rineka Cipta.

Notoadmojo. (2017). Konsep Pengetahuan. ABA Journal.

https://doi.org/10.1002/ejsp.2570

Notoatmodjo, P. (2015). Konsep Perilaku dan Perilaku Kesehatan. In Biomass Chem Eng.

Notoatmojo, S. (2010). Konsep perilaku kesehatan. Promosi Kesehatan, Teori Dan Aplikasi.

Nurchandra, D., Aulia, F., \& Mirawati. (2020). Pendidikan Kesehatan Tentang Personal Hygiene pada Remaja Putri di SMP 1 Muhammadiyah Banjarmasin. Jurnal Pengabdian Masyarakat Kebidanan.

https://doi.org/103.97.100.145/index. $\mathrm{php} / \mathrm{JPMK} /$ article/view/5368

Pratiwi, H., \& Rodiani, R. (2015). Obesitas sebagai Resiko Pemberat Dismenore pada Remaja. Medical Journal of Lampung University.

Prawirohardjo, S. (2016). ILMU KEBIDANAN Sarwono Prawirohardjo. In Edisi Ke-4. Jakarta: Yayasan Bina Pustaka Sarwono Prawirohardjo. https://doi.org/10.1017/CBO9781107 415324.004

Rahman, W. R., Hidayah, N., \& Azizah, N. (2014). Pengaruh Sikap, Pengetahuan, dan Praktik Vulva Hygiene dengan Kejadian Keputihan pada Remaja Putri di SMPN 01 Mayong Jepara. Jurnal Keperawatan Maternitas.

Randolph, L. K., \& Hopkins, M. P. (2015). Pruritus Vulvae. In The 5-Minute Clinical Consult Standard 2016: Twenty Fourth Edition.

Ríos Yuil, J. M., Castro, M. R., De Ríos, E. Y., \& Pérez, P. M. (2014). Prurito vulvar: Un desafío dermatológico. Dermatologia Cosmetica, Medica y Quirurgica.

Rohmawati, I. (2018). Pengaruh Pendidikan Kesehatan Melalui Media Video Terhadap Perilaku Vulva Hygiene Untuk Mencegah Keputihan Pada Remaja Putri Kelas VIII Di SMP N 1 Kec. Babadan Ponorogo. Journal of Chemical Information and Modeling. https://doi.org/10.1017/СВO9781107 415324.004

Sari, P. M. (2016). Hubungan Antara Pengetahuan Dan Sikap Remaja Dengan Kejadian Fluor Albus Remaja Putri Smkf X Kediri. Jurnal Wiyata. 
Setianingsih, A., \& Putri, N. A. (2017). Hubungan Pengetahuan dan Sikap Terhadap Perilaku Personal Hygiene Mentruasi. Jurnal Ilmu Kesehatan Masyarakat.

https://doi.org/10.33221/jikm.v5i4.15

Sugiyono. (2012). Metode Penelitian Kuantitatif, Kualitatif dan R \& D.Bandung:Alfabeta. Metode Penelitian Kuantitatif, Kualitatif Dan $R \quad \&$ D.Bandung:Alfabeta. https://doi.org/10.1017/CBO9781107 415324.004

Supatmi, \& Adyani, A. (2009). Tindakan Personal Hygine (Vulva Hygine) saat Menstruasi pada Siswi SMP Muhammadiyah X Surabaya. Fakultas Ilmu Kesehatan Universitas Muhammadiyah Surabaya.

Suryati. (2012). Perilaku Kebersihan Remaja Saat Menstruasi. Health Quality.

Timbawa, S., Kundre, R., \& Bataha, Y. (2015). Hubungan Vulva Hygiene Dengan Pencegahan Infeksi Luka Perineum Pada Ibu Post Partum di Rumah Sakit Pancaran Kasih Gmim Manado. Jurnal Keperawatan UNSRAT.

Tri, F., \& Indah, N. (2018). KEJADIAN PRURITUS VULVAE SAAT MENSTRUASI PADA REMAJA PUTERI ( Studi pada Siswi SMAN 1 Ngimbang Kabupaten Lamongan ). FKM Unair.

Wardani, R. S., \& Anggraini, N. N. (2015). Hubungan Tingkat Pendidikan Dan Pengetahuan Dengan Perilaku Perawatan Vulva Hygiene Pada Wanita di Lapas Semarang Tahun 2014. In Jurnal Kebidanan.

Winerungan, E., Hutagaol, E., \& Wowiling, F. (2013). Hubungan Pengetahuan Kesehatan Reproduksi Dengan Kejadian Iritasi Vagina Saat Menstruasi Pada Remaja di SMP Negeri 8 Manado. Jurnal Keperawatan UNSRAT. 